\title{
Fishing seasons of fish landed at Sungailiat Archipelago Fishing Port in Bangka Regency
}

\author{
Fauziyah $^{1^{*}}$, Fitri Agustriani ${ }^{1}$, Desi Melda Situmorang ${ }^{1}$, and Yuliyanto Suteja ${ }^{2}$ \\ ${ }^{1}$ Marine Science Department, Faculty of Mathematics and Natural Sciences, Sriwijaya University, \\ Indonesia \\ ${ }^{2}$ Marine Science Department, Faculty of Marine Sciences and Fisheries, Udayana University, \\ Indonesia.
}

\begin{abstract}
The fish landed at the Archipelago Fishing Port of Sungailiat is an important aspect for the fishing industry development. One of the factors that influence the sustainability of capture fisheries is optimal fishing operation. Fishing season index can be used to determine an appropriate time in perform of fishing operations. The objective of this research is to determine fishing season pattern of pelagic and demersal fish in the Archipelago Fishing Port of Sungailiat. Time series data on catch and fishing efforts (2006-2015) collected from Sungailiat Archipelago Fishing Port were used to calculate monthly CPUEs and then analysed using moving average method to obtain fishing season index for each month. This results showed that the peak fishing season of eastern little tuna and Barre spanish mackerel occur for 4 months with the best peak season respectively in October and April. The peak fishing season of Yelowstripe Scad, Tile Trevally, Terpedo Scad, sharks and Grouper occur for 5 months with the best peak season respectively in October, May, January, April, and February. The peak fishing season of Marine catfish and Black pomfret occur for 6 months with the best peak season respectively in January and October. While the peak fishing season of Ray occur for 8 months with the best peak season in October.
\end{abstract}

\section{Introduction}

The Sungailiat Archipelago Fishing Port (AFP) in Bangka Regency, Bangka Belitung Islands Province has a large potential as a center for the development of capture fisheries industry. Types of fish in the Sungailiat AFP are demersal fish, pelagic fish, crustaceans, and squid. Several species of demersal fish are landed such us eaglerays, ornate threadfin bream, leopard coralgrouper, black pomfret, yellowtail fusilier, marine catfish, red snappers and sharks. Deepbody sardinella, yelowstripe scad, narrow-barred spanish, terpedo scad, kawa-kawa, short bodied mackerel, tile trevally, indo-pacific sailfish, dorab wolf-herring, great barracuda and needlescale queenfish are an example of a landed pelagic fish.

* Corresponding author: siti_fauziyah@yahoo.com 
Fishing unit in Sungailiat AFP mostly under 10 GT with fishing gear used by fisherman include handline, drift gillnet, fixed gillnet, surrounding net, mini purse seine, and trap net.

Based on Sungailiat AFP production data for the last 10 years, the production of pelagic and demersal fish resources is fluctiative. The fluctuating production of fish resources is caused by human, availability of fish resources and environment factors. The availability of fish resources factor is strongly influenced by fish season pattern. One approach that can be used to determine the pattern of the fish season is to predict the fishing season pattern that is landed at the fishing port. Fishing season pattern is very useful for fishermen and government. For fishermen it is useful to determine the exact timing for fishing operations $[1,2]$ so that fishing activities are more planned and efficient [3]. For the government is useful for initial estimates of overfishing [4], more efficient and sustainable fisheries planning [3], utilization and management of fish resources [5, 6, 7], controlling and monitoring the rate of fishing exploitation [2].

Information and research on fishing season pattern that is landed in Sungailiat AFP is poor. Previous studies have only examined the pattern of cuttlefish fishing season [8]. Other studies were related to the technical efficiency of the bottom gillnet [9], the productivity model of the bottom gillnet [10], the finance analysis of bottom gillnet [11], the design characteristics of fishing boat for bottom gillnet [12], the static stability of fishing boat for bottom gillnet [13], bio-engineering of mackerel resources and marketing distribution [14], and bio-economic model of squid fisheries [15].

Based on research that has been done in Sungailiat AFP shows that the study of the fishing season pattern that were landed is very poor so it is difficult to describe the pattern of fish fishing season completely. Therefore, the pattern of the fishing season to be studied covers most of the demersal and pelagic fish landed at the Sungailiat AFP. It is hoped that this will provide a more complete conception of the diversity of fishing season pattern. This study aims to estimate the pattern of fish fishing season that landed at Sungailiat AFP. Information on fish fishing season pattern is needed to know the best time or season to catch the fish, thus reducing the risk of fishing loss. Furthermore, it is expected that the fishing operation will only be done in peak season, so that the optimum catch will be obtained and to keep the sustainability of fish resource [2].

\section{Materials and methods}

\subsection{Study site}

This study uses monthly data series of demersal and pelagic fish in 2006-2015. The data was collected by the managers of Sungailiat AFP. The data collected were pelagic fish (Eastern little tuna, Yelowstripe Scad, Barre spanish mackerel, Tile Trevally, and Terpedo Scad) and demersal fish (Marine catfish, Black pomfret, sharks, Ray, and Grouper).

\subsection{Data analysis}

Data analysis conducted in this research is analysis of catch per unit effort (CPUE), fishing gear standardization, and analysis of fishing season pattern using moving average method. 


\subsubsection{CPUE}

This analysis aims to determine the level of fish resource utilization of each species conducted by several fishing units used by fishermen. The CPUE equation $[16,4]$ was used as follows:

Where:

$$
C P U E_{i}=\frac{c_{i}}{f_{i}}
$$

$\mathrm{CPUE}_{\mathrm{i}}=$ the catch per unit of fishing effort in month $\mathrm{i}(\mathrm{kg} /$ trip)

$\mathrm{c}_{\mathrm{i}} \quad=$ the catch of fishing gear in month $\mathrm{i}(\mathrm{kg})$

$\mathrm{f}_{\mathrm{i}}=$ the effort of the fishing gear in month $\mathrm{i}$ (trip)

\subsubsection{Standardization of fishing gear}

Standardization of fishing gear was done by determining the largest CPUE of each fishing gear and the largest CPUE was used as a standard fishing gear. The stage standardization of fishing gear [17] as follows:

1. Determining the type of fishing gear that can be use as the standardized fishing gear, ie the fishing gear that has the largest CPUE value of each fishing gear.

2. Determine the value of Fishing Power Index (FPI) :

where:

$$
\begin{aligned}
& F P I_{i}=\frac{C P U E_{i}}{C P U E_{S}} \\
& F P I_{S}=\frac{C P U E_{S}}{C P U E_{S}}
\end{aligned}
$$

$\mathrm{FPI}_{\mathrm{i}}=$ Fishing Power Index of the fishing gear $\mathrm{i}$

$\mathrm{FPI}_{\mathrm{S}}=$ Fishing Power Index of the standardized fishing gear

$\mathrm{CPUE}_{\mathrm{i}}=$ The monthly CPUE of the fishing gear $\mathrm{i}(\mathrm{kg} /$ trip)

$\mathrm{CPUE}_{\mathrm{s}}=$ The monthly CPUE of the standardied fishing gear $(\mathrm{kg} /$ trip)

3. Calculating the total value of standard fishing effort.

where:

$$
\begin{gathered}
\text { StdEffort }_{s}=F P I_{s} x f_{s} \\
\text { Std Effort } \text { Ef }_{i}=F P I_{i} x f_{i} \\
\text { Std Effort } \text { total }_{\text {tal }}=\sum\left(F P I_{i} x f_{i}\right)+\left(F P I_{s} x f_{s}\right)
\end{gathered}
$$

$f_{i}$

$=$ the monthly fishing effort of the fishing gear i (trip)

fs

$=$ the monthly fishing effort of the standard fishing gear arbitrarily chosen (trip)

StdEffort $_{\mathrm{i}}=$ the standardized effort of the fishing gear $\mathrm{i}$ after standardization

StdEffort $_{\mathrm{s}}=$ the standardized effort of the standard fishing gear arbitrarily chosen, after standardization

StdEffort $_{\text {total }}=$ the standaridized effort of total fishing gears after standardization 


\subsubsection{Analysis of fishing season patterns}

Estimation of fishing season pattern was calculated per species with moving average method. This analysis was conducted by analyzing time series data on monthly data of catches of 12 species by fishing units that landed in Sungailiat AFP for 10 years. The steps of this analysis $[18,17]$ were :

1. Create a series of CPUE within 10 years period

$$
\mathrm{CPUE}_{I}=n_{i}
$$

where: $\quad n_{\mathrm{i}} \quad=$ CPUE of the $\mathrm{i}$-th order

$$
\mathrm{i} \quad=1,2,3 \ldots, 120
$$

2. Create a moving average CPUE for 12 months (MA)

$$
M A_{i}=\frac{1}{12}\left(\sum_{i=i-6}^{i+5} C P U E_{i}\right)
$$

where: $\quad \mathrm{MA}_{\mathrm{i}} \quad=$ the 12-month moving average of the $\mathrm{i}$-th order

$$
\begin{array}{ll}
\text { CPUE }_{\mathrm{i}} & =\text { CPUE of the } \mathrm{i} \text {-th order } \\
\mathrm{i} & =7,8,9 \ldots, \mathrm{n}-5
\end{array}
$$

3. Create a centered CPUE moving average (CMA)

$$
C M A_{i}=\frac{1}{2}\left(\sum_{i=i}^{i=1} M A_{i}\right)
$$

where: $\quad \mathrm{CMA}_{\mathrm{i}} \quad=$ centered moving average of CPUE in month $\mathrm{i}$

$$
\mathrm{i} \quad=7,8,9 \ldots, \mathrm{n}-5
$$

4. Create monthly average rasio

$$
A m_{i}=\frac{C P U E_{i}}{C M A_{i}}
$$

where:

$$
\begin{array}{ll}
\mathrm{Am}_{\mathrm{i}} & =\text { monthly average rasio in month } \mathrm{i} \\
\mathrm{CPUE}_{\mathrm{i}} & =\text { CPUE in month } \mathrm{i} \\
\mathrm{CMA}_{\mathrm{i}} & =\text { centered moving average of CPUE in month } \mathrm{i}
\end{array}
$$

5. Create an average value in ixj matrix organized for each month

6. Create average ratio for month i $\left(\mathrm{AAm}_{\mathrm{i}}\right)$

$$
A A m_{i}=\frac{1}{n}\left(\sum_{j=1}^{n} A m_{i j}\right)
$$

where: $\quad \mathrm{AAm}_{\mathrm{i}}=$ average for $\mathrm{Am}_{\mathrm{ij}} \mathrm{i}$-th month

$\mathrm{Am}_{\mathrm{ij}}=$ the monthly average ratio in the $\mathrm{i} \mathrm{x} \mathrm{j}$ size matrix

$\mathrm{i}=1,2,3, \ldots, 12$

$\mathrm{j}=1,2,3, \ldots, \mathrm{n}$

7. The total of monthly average ratios (TAM)

$$
\begin{array}{ll} 
& T A M=\sum_{i=1}^{12} A A m_{i} \\
\text { where: } & \text { TAM } \quad=\text { total of monthly average ratios }
\end{array}
$$

8. Fishing season Index (FSI)

Ideally, the TAM value is 1200 , but many factors cause TAM to not always equal to 1200 , therefore the value of the monthly average ratio should be corrected called the Correction Factor (CF) 
Decision criteria:

$$
\begin{aligned}
& C F=\frac{1200}{T A M} \\
& F S I_{i}=A A m_{i} \times C F
\end{aligned}
$$

$$
\begin{array}{ll}
\text { FSI } \geq 100 \% & : \text { peak season } \\
50 \% \leq \text { FSI }<100 \% & : \text { moderate season } \\
\text { FSI }<50 \% & : \text { low season }
\end{array}
$$

\section{Result}

\subsection{Production and CPUE}

Fish landed in Sungailiat AFP are generally produced by one or two types of fishing gear (Table 1). When one type of fish was produced by 2 types of fishing gear, then one of them was used as a standard fishing gear

Table 1. Types of fish produced by fishing gear at Sungailiat AFP

\begin{tabular}{|l|l|l|l|l|}
\hline \multicolumn{1}{|c|}{$\begin{array}{c}\text { Local } \\
\text { name }\end{array}$} & Common name & Habitat & \multicolumn{1}{|c|}{ Fishing gear } & $\begin{array}{c}\text { Standardized } \\
\text { fishing gear }\end{array}$ \\
\hline Selar & Yelowstripe Scad & P & $\begin{array}{l}\text { Handline, Surrounding } \\
\text { net }\end{array}$ & $\begin{array}{l}\text { Surrounding } \\
\text { net }\end{array}$ \\
\hline Kwee & Tile Trevally & P & Handline, trap net & Handline \\
\hline Tongkol & Eastern little tuna & P & Drift gillnet & Drift gillnet \\
\hline Tenggiri & $\begin{array}{l}\text { Barre spanish } \\
\text { mackerel }\end{array}$ & P & Handline, Drift gillnet & Drift gillnet \\
\hline Tetengkek & Terpedo Scad & P & Handline, Drift gillnet & Drift gillnet \\
\hline Manyung & Marine catfish & D & Handline, Fixed gillnet & Fixed gillnet \\
\hline Cucut & Sharks & D & Handline, Fixed gillnet & Fixed gillnet \\
\hline $\begin{array}{l}\text { Bawal } \\
\text { hitam }\end{array}$ & Black pomfret & D & Surrounding net & $\begin{array}{l}\text { Surrounding } \\
\text { net }\end{array}$ \\
\hline Pari & Ray & D & Handline, Fixed gillnet & Fixed gillnet \\
\hline Kerapu & Grouper & D & Handline, Trap net & Trap net \\
\hline \multicolumn{2}{|l|}{ P : Pelagic Demersal } &
\end{tabular}

Total production of 5 pelagic fish species landed in Sungailiat AFP (Figure 1) in 20062015 was fluctuated. The lowest production occurred in 2009 and the highest in 2015. In 2015 the production of Eastern Little Tuna, Barre Spanish Mackerel, Tile Trevally, and Terpedo Scad decreased compared to 2014, but the production of Yelowstripe Scad increased dractically. The total production of 5 demersal fish species landed in Sungailiat AFP (Figure 2) increase from 2006 to 2011 and then declined until 2015. The highest total production of demersal fish occurred in 2011 and the lowest in 2015. The highest demersal fish production every year was Ray. The production of Ray was almost annually greater 
than Yelowstripe Scad, except production in 2013 and 2015. Production of Yelowstripe Scad in 2015 tends to increase, in contrast to Ray that tends to decline.

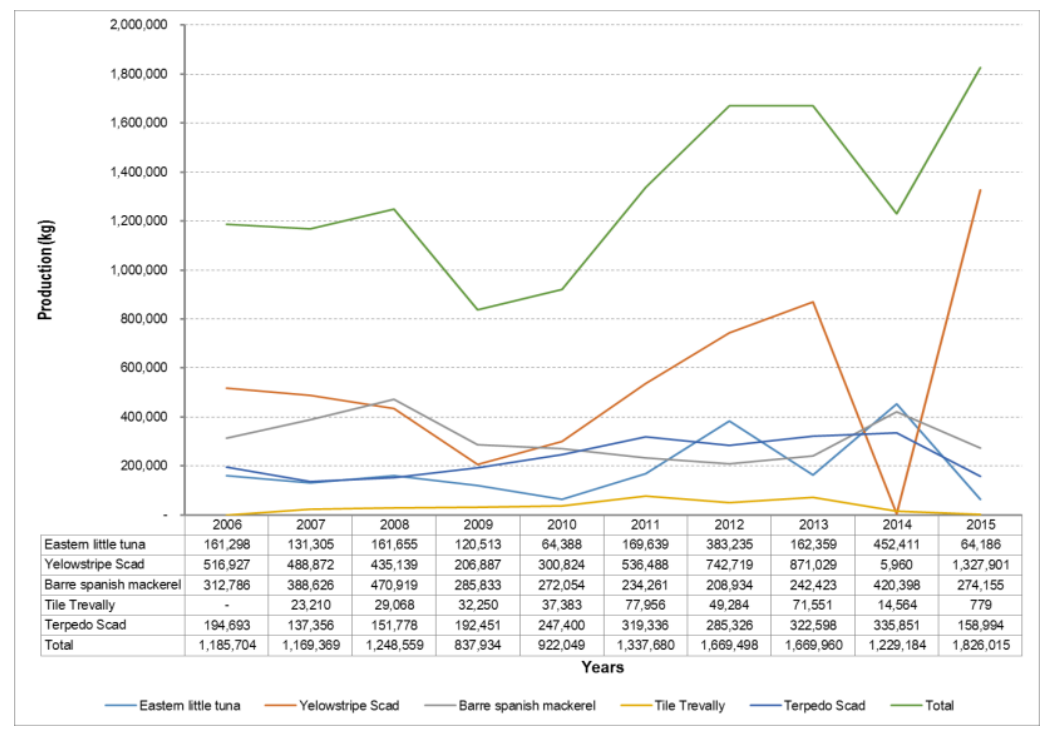

Fig 1. The production of 5 pelagic fish species landed in Sungailiat AFP

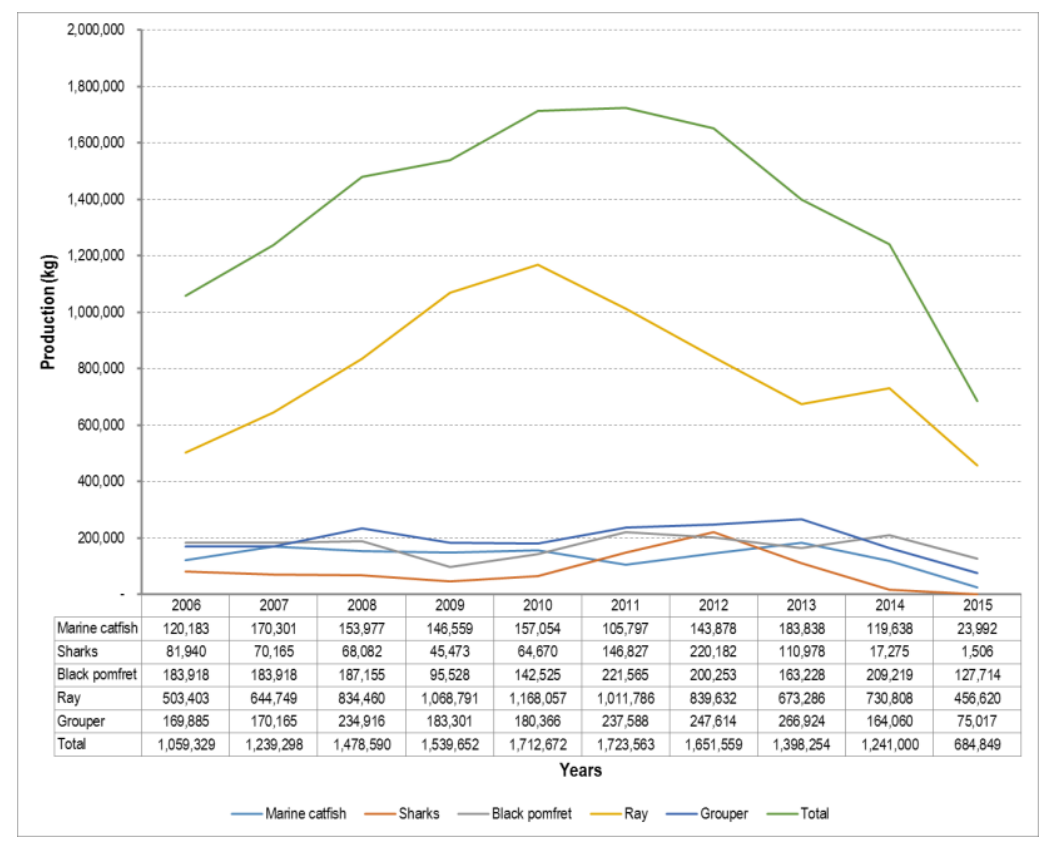

Fig2. The production of 5 demersal fish species landed in Sungailiat AFP

Based on the CPUE value (Figure 3), Yelowstripe Scad almost has the highest CPUE value throughout the year compared to other pelagic fish species. In 2006-2009 there was a decline of Yelowstripe Scad CPUE value and then increased until 2015. The same results 
were also obtained in Yelowstripe Scad production in Sunda Strait in 2006-2013 [19]. The CPUE value of rays (Figure 4) is highest throughout the year when compared to other demersal fish species. CPUE values of Ray were more fluctuated than Yelowstripe Scad. Fish resources (demersal and pelagic) landed on Sungailiat AFP have a fluctuating CPUE value pattern (Figure 3 and figure 4). The increase in CPUE values shows the average increase in catch per trip of the catching unit (improving the performance of the fishing gear used) and vice versa. Decrease in CPUE is one of the over fishing indicators [20].

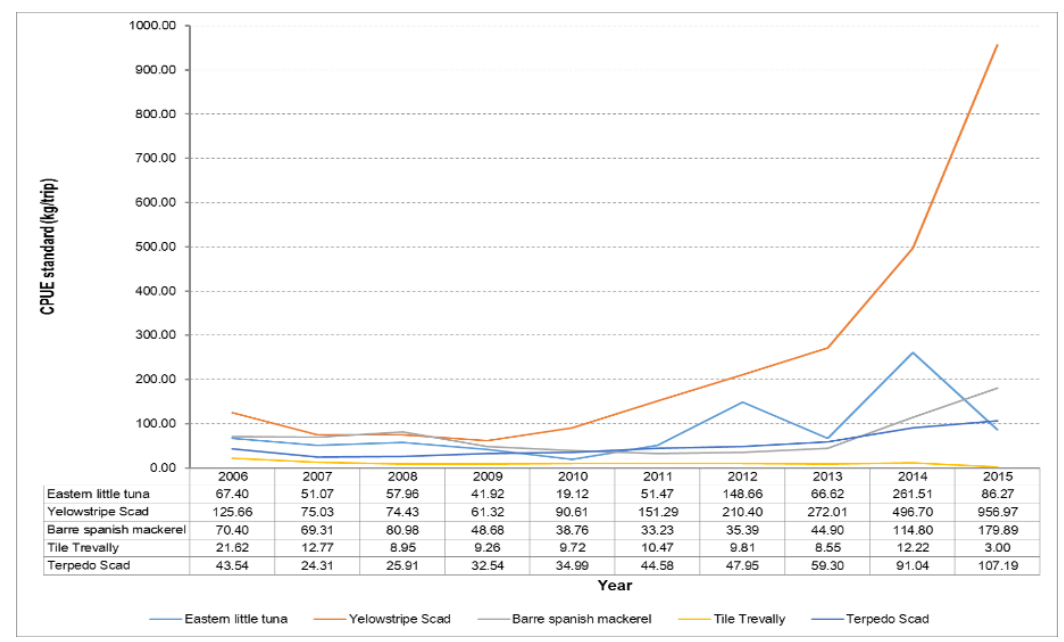

Fig 3. The CPUE of 5 pelagic fish species landed in Sungailiat AFP

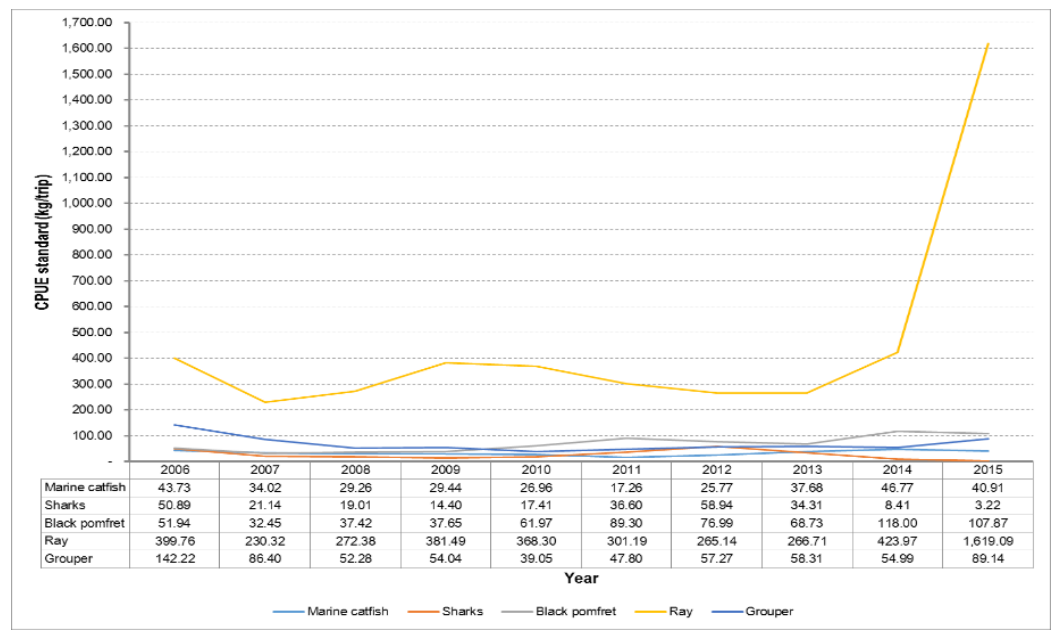

Fig 4. The CPUE of 5 demersal fish species landed in Sungailiat AFP

\subsection{Fishing season patterns}

Based on the value of fishing season index (Table 2), the peak season of pelagic fishing occurred in first transition season (March - May) and second transitional season (September 
- November). In dry season (June-August) and wet season (December-February) were predominantly moderate season.

Table 2. Recapitulation of pelagic fish fishing season

\begin{tabular}{|c|c|c|c|c|c|c|c|c|c|c|c|c|}
\hline \multirow{3}{*}{$\begin{array}{l}\text { Pelagic } \\
\text { Fish }\end{array}$} & \multicolumn{12}{|c|}{ Fishing Season Index } \\
\hline & \multicolumn{3}{|c|}{ Wet Season } & \multicolumn{3}{|c|}{$\begin{array}{c}\text { First Transition } \\
\text { Season }\end{array}$} & \multicolumn{3}{|c|}{ Dry Season } & \multicolumn{3}{|c|}{$\begin{array}{c}\text { Second } \\
\text { Transition } \\
\text { Season } \\
\end{array}$} \\
\hline & Dec & Jan & Feb & $\begin{array}{c}\mathbf{M a} \\
\mathbf{r}\end{array}$ & Apr & May & Jun & Jul & Aug & Sept & Oct & Nov \\
\hline $\begin{array}{l}\text { Eastern } \\
\text { little tuna }\end{array}$ & 75 & $40^{\mathrm{F}}$ & 95 & $\underset{P}{103}$ & 72 & $45^{\mathrm{F}}$ & 59 & 60 & 97 & $125^{\mathrm{P}}$ & $\underset{\mathrm{P}}{229}$ & $\underset{\mathrm{P}}{199}$ \\
\hline $\begin{array}{l}\text { Yelowstri } \\
\text { pe Scad }\end{array}$ & 87 & 78 & $102^{\mathrm{P}}$ & 99 & $101^{\mathrm{P}}$ & 98 & 90 & 94 & 90 & $110^{\mathrm{P}}$ & $\underset{\mathrm{P}}{128}$ & $\underset{\mathrm{P}}{122}$ \\
\hline $\begin{array}{l}\text { Barre } \\
\text { spanish } \\
\text { mackerel }\end{array}$ & 70 & 75 & 98 & 134 & $141^{\mathrm{P}}$ & 97 & 93 & 95 & 80 & 87 & $\underset{\mathrm{P}}{107}$ & $\underset{\mathrm{P}}{123}$ \\
\hline $\begin{array}{l}\text { Tile } \\
\text { Trevally }\end{array}$ & 94 & 58 & $107^{\mathrm{P}}$ & 95 & $103^{\mathrm{P}}$ & $162^{\mathrm{P}}$ & 89 & 84 & 86 & 85 & 130 & 106 \\
\hline $\begin{array}{l}\text { Terpedo } \\
\text { Scad }\end{array}$ & 90 & $133^{\mathrm{P}}$ & $130^{\mathrm{P}}$ & 96 & $125^{\mathrm{P}}$ & $101^{\mathrm{P}}$ & 93 & 90 & 69 & 75 & 92 & $\underset{P}{106}$ \\
\hline
\end{tabular}

Peak fishing season of Eastern Little Tuna occurs for 4 months ie March, September, October, and November (most of the 2nd transition season) with the best peak season in October. Similar result also found in Prigri AFP, peak season of tuna occurs in April-June and August-November [21]. At Baron beach (southern waters of Yogyakarta), peak fishing season occurs in July-October with the highest peak occurring in October [22]. In Lempasing Coastal Fishing Port (Lampung Bay), peak catch season occurred in April, July, August, September and October [5].

Peak fishing season of Yelowstripe Scad occurs for 5 months ie February, April, September, October, and November with the best peak season occurring in October. In the Java Sea, fishing season other species Yelowstripe Scad (Selar crumenophthalmus) occurred in December [23].

Peak fishing season of Barre Spanish Mackerel occurs for 4 months ie March, April, October, and November with the best peak season occurring in April. These results were different from the fishing season at Lempasing Coastal Fishing Port (Lampung Bay) where the fishing season of Barre Spanish Mackerel occurs in March, May, July, August, and September [5]. In the Java Sea [24], Barre Spanish Mackerel fish abundance in March to June and in October to December throughout the year.

Peak fishing season of Tile Trevally occurs for 5 months ie February, April, May, October, and November with the best peak season occurring in May. Peak fishing season of Terpedo Scad occurs for 5 months ie January, February, April, May and November with the best peak season occurring in January. The previous research in Lampung Bay mentioned that the fishing season of Tile Trevally occurred in January, April, June, September, November, and December [5]. In the dry season, pelagic fish catches were in moderate season. The low season occurs only in Eastern little tuna in January and May. Peak season mostly occurs in first and second transition season II. 
The demersal fishing season (Table 3) has a similar pattern to the pelagic fishing season (Table 2). In the dry season and wet season, the captured of the five species of demersal fish were mostly in the moderate season, whereas, during the first and second transition season were mostly in the peak season.

The fishing season peak of Marine Catfish occurs for 6 months during wet and first transition season with the best peak season occurring in April. The similar result also found in Pelabuhanratu (west java), the peak season of Marine Catfish occurred in January, February, September and October [25].

Table 3. Recapitulation of demersal fish fishing season

\begin{tabular}{lccccccccccccc}
\hline & \multicolumn{10}{c}{ Fishing Season Index } \\
\cline { 2 - 13 } Demersal Fish & \multicolumn{1}{c}{ First Transition } & \multicolumn{1}{c}{ First Transition } & \multicolumn{3}{c}{ First Transition } & \multicolumn{3}{c}{ First Transition } \\
& \multicolumn{3}{c}{ Season } & \multicolumn{3}{c}{ Season } & \multicolumn{3}{c}{ Season } & \multicolumn{3}{c}{ Season } \\
\cline { 2 - 15 } & Dec & Jan & Feb & Mar & Apr & May & Jun & Jul & Aug & Sept & Oct & Nov \\
\hline Marine catfish & $104^{\mathrm{P}}$ & $119^{\mathrm{P}}$ & $112^{\mathrm{P}}$ & $101^{\mathrm{P}}$ & $116^{\mathrm{P}}$ & $104^{\mathrm{P}}$ & 82 & 91 & 93 & 92 & 89 & 96 \\
Sharks & 86 & 65 & 96 & $112^{\mathrm{P}}$ & $146^{\mathrm{P}}$ & $118^{\mathrm{P}}$ & 93 & 91 & 82 & 87 & $117^{\mathrm{P}}$ & $107^{\mathrm{P}}$ \\
Black pomfret & 97 & $105^{\mathrm{P}}$ & $125^{\mathrm{P}}$ & $118^{\mathrm{P}}$ & 76 & 88 & 62 & 76 & 68 & $113^{\mathrm{P}}$ & $146^{\mathrm{P}}$ & $125^{\mathrm{P}}$ \\
Ray & 85 & $45^{\mathrm{F}}$ & $112^{\mathrm{P}}$ & $121^{\mathrm{P}}$ & 77 & $109^{\mathrm{P}}$ & $115^{\mathrm{P}}$ & $104^{\mathrm{P}}$ & 90 & $103^{\mathrm{P}}$ & $123^{\mathrm{P}}$ & $115^{\mathrm{P}}$ \\
Grouper & 73 & 81 & $167^{\mathrm{P}}$ & $111^{\mathrm{P}}$ & 98 & $101^{\mathrm{P}}$ & $118^{\mathrm{P}}$ & $100^{\mathrm{P}}$ & 89 & 82 & 96 & 84 \\
\hline
\end{tabular}

The fishing season peak Shark occurs for 5 months ie March, April, May, October and November (first and second transition season) with the best peak season occurring in April. This result is slightly different from the fishing season Kejawaan AFP (Cirebon) where the peak season occurs in the east season [26]. In the Pelabuhanratu AFP (Sukabumi), peak season of shark occurred in January, April, May, June July, August, September and December [25]. The fishing season peak Black Pomfret occurs for 6 months ie January to March and September to November with the best peak season occurring in October.

The Ray have the longest peak fishing season ( 8 months) ie February, March, May, June, July, September, October and November with the peak season occurred in October. The fishing season peak of Grouper occurs for 5 months ie February, March, May, June, and July with the highest peak season occurring in February. The low season occurs only in Ray, which was in January.

Table 2 and Table 3 also show that in December was not the peak season for both pelagic and demersal at Sungailiat AFP. This was thought to be due to the high of wind speed, waves and rainfall [3] it makes fish resources move into the open seas and affect the distribution of fishing season [27]. The movement of these fish will change the distribution and abundance of fish in fishing ground. The decrease of fish abundance in fishing ground will decrease catch per trip [3]. The fishing activities conducted in the west season was ineffective so the fishermen in AFP Sungailiat reduced the trips in those months [8]. During wet season (low season), the fish is still caught by the fishermen although the number of catches per trip is very low [28].

\section{Conclusion}

The peak fishing season of eastern little tuna and barre spanish mackerel occur for 4 months with the best peak season respectively in October and April. The peak fishing season of yelowstripe scad, tile trevally, terpedo scad, sharks and grouper occur for 5 
months with the best peak season respectively in October, May, January, April, and February. The peak fishing season of marine catfish and black pomfret occur for 6 months with the best peak season respectively in January and October. While the peak fishing season of Ray occur for 8 months with the best peak season in October.

We would like to thank UNSRI for the support of DIPA-UNSRI funds in 2016 through competitive scheme and to AFP Sungailiat of Bangka Regency of Bangka Belitung Province

\section{References}

1. M. Syahrir, M.S. Baskoro, Darmawan, E. Lubis, E.S. Wiyono, J. Ilmu Per. Trop. 13, 24-31 (2010)

2. D. Simbolon, B. Wiryawan, P.I. Wahyuningrum, H. Wahyudi, Bul. PSP 19, 293-307 (2011)

3. J.S. Kekenusa, V.N.R. Warung, D. Hatidja, J. Ilm. Sains 12, 112-119 (2012)

4. E. Hamka, M. Rais, J. Ipt. PSP 3, 510-517 (2016)

5. S. Agustina, R. Irnawati, A Susanto, J. Per. Kel. 6, 74-82 (2016).

6. C.J. Lintang, I.L. Labaro, A.T.R. Telleng, J. ITK Tangkap 1, 6-9 (2012).

7. Mustasim, J. Airaha 5, 83-86 (2016)

8. D. Rosalina, W. Adi, D. Martasari, Maspari J. 2, 26-38 (2011).

9. T. Afridanelly, Fauziyah, F. Agustriani, Maspari J. 2, 74-76 (2011).

10. Fauziyah, F. Agustriani, T Afridanelly, J. Pen. Sains 14, 56-60 (2011).

11. T.S. Rahmawati, R Aryawati, F. Agustriani F, Maspari J. 2, 70-73 (2011).

12. R. Pasaribu, Fauziyah, F. Agustriani, Maspari J. 2, 54-62 (2011).

13. R. Nopandri, Fauziyah, Rosdirwan, Maspari J. 2, 63-69 (2011).

14. M.P. Sobari, A. Febrianto, MARITEK 10, 15-29 (2010).

15. W. Oktariza, B. Wiryawan, M.S. Baskoro, R. Kurnia, S.H. Wisudo, Mar. Fish. 7, 97-107 (2016).

16. P. Sparre, S.C. Venema, Introduction to tropical fish stock assessment. Part 1. Manual. (Rome, FAO, 1998) http://www.fao.org/docrep/w5449e/w5449e01.htm

17. L.I. Azkia, A.D.P. Fitri, I. Triarso, J. Fish. Res. Uti. Man. Tech. 4, 1-7 (2015).

18. R.I. Wahyu, Zulkarnain, K.P.S. Mara, Bul. PSP 19, 105-113 (2011).

19. M. Sharfina, M. Boer, Y. Ernawati, Mar. Fish. 5, 101-108 (2014).

20. R.T. Cahyani, A. Sutrisno, Y Bambang, Pros. Seminar Nasional Pengelolaan Sumberdaya Alam dan Lingkungan 378 -383 (2013).

21. A. Wujdi, Suwarso, Simp. Nas. Pengelolaan Perikanan Tuna Berkelanjutan Bali, 10-11 Desember 2014.

22. I. Nahib, D. Sutrisno, Globë 12, 9-20 (2010).

23. U. Chodrijah, T. Hartiati, J. Pen. Per. Indo. 3 (2010)

24. K. Kasim, S. Triharyuni, J. Pen. Per. Indo. 4 (2014)

25. R.S.N. Sulistiawan, D. Martiani, J. Agrosci. 4, 40-55 (2012).

26. R. Fakhrurrizal, Shutabarat, A, Hartoko, Diponegoro J. Maq. 3, 71-80 (2014).

27. G. Respondek, J. Groger, J. Floeter, A. Temming, ICES J. Mar. Sci. 71, 1805-17 (2014).

28. H. Ilhamdi, R. Telussa, D. Ernaningsih, J. Ilm. Sat. Min. Bah. 1, 52-64 (2016). 